I might mention that the albumen was used emperically, as we had found in alloplastic operations that we dipping the flap in albumen previous to adjustment produced excellent effects. Whether it assists in nourishing the transplanted tissue, or on account of its adhesiveness that it is of advantage, has yet to be determined.

THE HYPODERMIC ADMINISTRATION OF MORPHINE AS A SUBSTITUTE FOR HANGING IN THE EXECUTION OF CRIMINALS. ${ }^{1}$

BY FREDERICK HENRY GERRISH, M.D.

Surgeon to the Maine General Hospital, Professor of Anatomy in Boudoin College, etc.

CAPITAL punishment is an approved method of dealing with certain classes of criminals in Maine. Within a few weeks two men have suffered this extreme penalty in the state prison; two more men and a woman are to be executed there before the year ends; and, judging from the frequency of murder of late, and the apparently growing disregard of the sanctity of human life, the number of persons whom the State will desire to exterminate annually in the future will be not less than that judicially killed in 1885. In view of this condition of affairs, it behooves the medical profession, which, more than any other class, has knowledge of the processes of living and of dying, to consider the means adopted by the legal authorities for taking lives which have been forfeited to the State, to decide whether or not these methods are humane, and to advise the law-makers concerning improvements, if any, are necessary and possible. I bring this subject to your notice because of my conviction that the present usage is antiquated and barbarous, and because a substitute for it can readily be found which is free from objectionable features.

It is not my purpose to attempt a historical account of execution by hanging. Suffice it to say that it has long been the favorite method of putting criminals to death in the English-speaking countries, and was doubtless adopted on account of its supposed superiority to others in point of humanity. That hanging is sometimes sudden, painless, and as free from hideous display as such a process well can be, is freely admitted; but that it is often slow, painful, and altogether horrible, is known to all men. Occasionally the rope breaks, and the victim falls to the ground, only to be picked up and dragged again to the scaffold, to experience once more the bitterness of death. Once in a while the long drop effects decapitation, and we have the bloodiness of the guillotine, without the neatness of its cut.

Last winter in England a condemned man was on the scaffold, the last words had been spoken, the bolt was drawn, but the drop did not fall. The convict was removed, the apparatus was tested, and again the intended victim was put in position. A second and a third time did the drop fail to act when released, and then the poor fellow, who had thrice looked death calmly in the face, fainted and was carried back to his cell. His sentence was commuted, and the people said Amen. So frequent are the bunglings and failures, that those who have the business in charge are always nervous till the affair is over. Said the assistant-warden, in response to a congratulation on the success of the recent hanging at Thomaston, "Yes, it passed off

1 Read before the Mrine Medical Association, June 9, 1885. well ; but we have been very anxious about it for three weeks. The last one we had here was not so successful!" Indeed, it was not, as any one who witnessed it can testify. I have no hesitancy in pronouncing so imperfect and cruel a method of taking human life, entirely unworthy of the civilization of the nineteenth century.

In our search for a substitute, we naturally consider the methods employed by other nations, and we find that none of them possess qualities which commend them to our judgment. The guillotine, the garrote, and shooting, while presenting certain advantages, would, for obvious reasons, never find favor with AngloSaxons of this age, and crucifixion is not to be thought of. Electricity has been advocated; but the apparatus for an execution would be very expensive, and it is not certain that the result would be satisfactory ; for many times men have received electric shocks which anybody would have supposed sufficient to cause death, and have recovered. Chloroform has been suggested; but the administration of this drug might require a considerable time, and there would always be a strong probability of struggling and delirium, with the wild shouts, and yells, and imprecations. Prussic acid might be used, but for the danger to which the anhydrous article would expose the person administering it, and the chance of convulsions resulting from a dose not immediately paralyzing to the powers of life.

The method which seems best to me is the hypodermic administration of morphine in a lethal dose. I am not aware that it has been proposed before; at all events, the plan is new to those to whom I have mentioned it, and seems worthy of serious consideration.

The details of the execution would be as follows:-

At the appointed time, the sheriff, accompanied by two deputies and the citizens prescribed by statute, enters the cell of the convict, who is lying on a couch. The sheriff administers six grains of sulphate of morphine under the skin of the felon, who, in a few moments begins to be drowsy. Soon he is overpowered with sleep, and the officer, to make assurance doubly secure, repeats the dose. Within half an hour the heart has ceased to beat, and the man is dead, having passed away without pain, convulsion, struggle, or consciousness.

The advantages of this method are its certainty, its painlessness, the freedom from the chance of horrible displays, the reduction of the dramatic element to a minimum, and its inexpensiveness.

(1) No one will dispute the certainty of the result. If anybody fears thas the dose is too small, it can be repeated over and over again, so that the end may be greatly hastened. There is no possibility of the rejection of the poison.

(2) The convict is caused no suffering, for the slight sting of the hypodermic injection is unworthy to be called pain.

(3) There are no convulsions, no decapitation, none of the hideous phenomena that often attend a hanging; the man simply goes to sleep, never to awake.

(4) Many of the criminals who are condemned to death, and find that a change of punishment is impossible, make the most of their situation, and try to glorify themselves in the eyes of their friends by "dying game" on the gallows, and carrying themselves jauntily on the threshold of eternity. The exclusion of the public from executions has greatly diminished the opportunities for spectacular display; but the quiet and 
seclusion of the cell in which the fatal dose of morphine is taken reduce these chances to their very lowest terms. A villain on the scaffold, in full possession of his faculties, anticipating instant extinction, may appear heroic; the same man submitting to the trivial puncture of a hypodermic needle, and presently becoming too stupid to keep his eyes open, is far less likely to consider himself, or be thought by others, a hero.

(5) The cost of erecting the gallows is considerable; that of a hypodermic syringe and morphine insignificant. It may be a small matter to discuss; but, after the State has been at the expense which a murder-trial usually costs, generally paying the fees of the defendant's counsel, as well as those of the prosecution, it is not improper to desire that the last act of the tragedy may be as inexpensive as possible.

Various objections are made to the proposed change, and these will be considered and answered seriatim.

(a) It is said that the sheriff cannot inject the morphine skilfully. If one but recalls the ease with which he himself learned how to use the hypodermic syringe, and the namber of people in his acquaintance who acquired all too readily the necessary skill for administering doses to themselves, he will see the weakness of this objection.

(b) The slowness of the dying is thought to be undrirable. But in this, as in other affairs, the thing is quilkkly enough done, when it is well enough done. At the worst, the time will not be very long, and every minute will show that the man is sinking into a rapidly deepening sleep.

(c) It is suggested that convicts might be opiumeaters, or might train themselves so that their nervous systems would be incapable of receiving a fatal impression from morphine. To say nothing of the supposition that any person might not be poisoned to death by morphine, it is to be observed that the law requires that the time for execution shall be not less than twelve months from the day on which the sentence is passed, in which time, as the state does not supply its prisoners with drugs to be taken for merely intoxicant effects, the opium-habit would be cured, or its slave be dead, - an arrangement to which nobody would object.

(d) It is objected that the publicity of an execution is diminished by the projected method, and the chance to impress the people is lost. The present law allows but few to attend an execution, evidently with the design of avoiding publicity, for the effect on the community of an old-fashioned hanging was believed to be extremely harmful. A sufficient impression is made on the populace by the announcement of the fulfilment of the law; the chief purpose of which is the permanent removal of a worse than worthless member of society.

(e) Some have said that they do not object to having felons endure some physical pain. Obviously the people do not entertain such views; for they have abolished torture and those forms of execution which are always painful, like crucifixion; and I believe they have retained hanging so long only because no plainly better plan has been advocated. The effort always is to make the death by hanging as sudden and painless as possible; and, when it is not so, we blame the executioner.

$(f)$ It is objected that criminals dread death by hanging more than they would that by morphine, and thus are deterred from committing deeds which they would venture upon, if an easy poison were substituted for the rope. This seems to me in the highest degree improbable; but the discussion of the point would inevitably lead to the re-opening of the question of the value of capital punishment, a subject which it would be improper to introduce here. It is well, however, to remember that the deprivation of opportunity for a dramatic exhibition would be so serious a matter to a convict that it would be almost like adding a sting to death.

In the distant future there will probably be judicial processes by which undesired lives other than those of criminals may be brought to an end. How often we have reason to wish for such a law, for the sake of those whose usefulness and happiness are blighted by the existence of some hopelessly demented dependent, who demands constant attendance; what a blessing it would be to the poor wretch smitten with an unevitably fatal disease, racked with unceasing pain, a nuisance to himself and a grievous burden to those whom he loves. If such a statute were in existence now, and it were given to us to decide what method should be pursued for bringing the unwished for existence to a close, would not every one of us write on his note morphine? And would we not choose this poison because accident has shown us many times that death by it is like another sleep, is painless, quiet, and not disfiguring? 'These are the very characteristics of the typical execution, qualities which hanging often has not, but.which, I predict, the judicial killing of the future will always exhibit.

\section{RECEN'T PROGRESS IN ANATOMY.}

$$
\text { BY THOMAS DWIGHT, M.D. }
$$

THE RELATIONS OF THE LARYNX AND TRACHEA TO THE VERTEBRAL COLUMN IN THE FETUS AND CHIID.

Mr. J. Symington has written an excellent paper on the position of the epiglottis, the lower border of the cricoid and the bifurcation of the trachea in fotuses and young children. He has had recourse to frozen sections and has carefully noticed the position of the head in each case, as this seems to exercise an influence on the relation of the parts. He has examined in this way five fotuses, seven children up to two years and two months, and three children of five, six and thirteen years, respectively. A greater number is, of course, desirable, but these observations form a nucleus. To show the effect of position of the head, Mr. Symington cites the freezing of the bodies of two children about two years old and of just the same length, one with the neck strongly flexed and the other with it well extended. In the former, the lower border of the cricoid was at the level of the upper border of the sixth cervical vertebra, in the latter, it was a vertebra higher. In the former, the bifurcation was opposite the lower border of the fourth dorsal, in the latter, opposite the upper border of the third. The series shows a gradual descent of the lower border of the cricoid. In the youngest fotus, one of about four months, it was opposite the upper border of the fourth cervical. In a child of three and a half months, it was at the lower border of the fourth, and at one of six months, at the upper border of the fifth. It does not 